NBER WORKING PAPER SERIES

\title{
WEALTH DESTRUCTION ON A MASSIVE SCALE? \\ A STUDY OF ACQUIRING-FIRM RETURNS \\ IN THE RECENT MERGER WAVE
}

\author{
Sara B. Moeller \\ Frederik P. Schlingemann \\ René M. Stulz \\ Working Paper 10200 \\ http://www.nber.org/papers/w10200
}
NATIONAL BUREAU OF ECONOMIC RESEARCH
1050 Massachusetts Avenue
Cambridge, MA 02138
December 2003

\begin{abstract}
We are especially grateful to Harry DeAngelo, Linda DeAngelo and David Hirshleifer for comments and discussions. We thank Asli Arikan, Michael Jensen, Jean Helwege, Andrew Karolyi, Rick Green, Henri Servaes, Andrei Shleifer, Mike Smith, Ralph Walkling, seminar participants at Ohio State and the NBER, and two anonymous referees for comments. Mehmet Yalin provided excellent research assistance. The views expressed herein are those of the authors and not necessarily those of the National Bureau of Economic Research.

(C)2003 by Sara B. Moeller, Frederik P. Schlingemann, and René M. Stulz. All rights reserved. Short sections of text, not to exceed two paragraphs, may be quoted without explicit permission provided that full credit, including (C) notice, is given to the source.
\end{abstract}


Wealth Destruction on a Massive Scale? A Study of Acquiring-Firm Returns in the Recent Merger Wave

Sara B. Moeller, Frederik P. Schlingemann, and René M. Stulz

NBER Working Paper No. 10200

December 2003

JEL No. G31, G32, G34

\begin{abstract}
Acquiring-firm shareholders lost 12 cents at the announcement of acquisitions for every dollar spent on acquisitions for a total loss of $\$ 240$ billion from 1998 through 2001 , whereas they lost $\$ 7$ billion in all of the 1980 s, or 1.6 cents per dollar spent. Though the announcement losses to acquiring-firm shareholders in the 1980s are more than offset by gains to acquired-firm shareholders, the losses of bidders exceed the gains of targets from 1998 through 2001 by $\$ 134$ billion. The 1998-2001 aggregate dollar loss of acquiring-firm shareholders is so large because of a small number of acquisition announcements by firms with extremely high valuations. Without these announcements, the wealth of acquiring-firm shareholders would have increased. The large losses are consistent with the existence of negative synergies from the acquisitions, but the size of the losses in relation to the consideration paid for the acquisitions is large enough that part of the losses most likely results from investors reassessing the standalone value of the bidders. Firms that announce acquisitions with large dollar losses perform poorly afterwards.
\end{abstract}

Sara B. Moeller

Cox School of Business

Southern Methodist University

smoeller@mail.cox.smu.edu

Frederik P. Schlingemann

Katz Graduate School of Business

University of Pittsburgh

schlinge@katz.pitt.edu
Rene M. Stulz

Fisher College of Business

Ohio State University

806A Fisher Hall

2100 Neil Avenue

Columbus, OH 43210-1144

and NBER

stulz@cob.osu.edu 


\section{Introduction}

In this paper, we examine the experience of acquiring-firm shareholders in the recent merger wave and compare it to their experience in the merger wave of the 1980s. Such an investigation is important because the recent merger wave is the largest by far in American history. It is associated with higher stock valuations, greater use of equity as a form of payment for transactions, and more takeover defenses in place than the merger wave of the 1980s. ${ }^{1}$ Though these differences suggest poorer returns for acquiring-firm shareholders, there are also several reasons why the acquiring-firm shareholders may have better returns. With the growth of options as a form of managerial compensation in the $1990 \mathrm{~s}$, managerial wealth is more closely tied to stock prices, making management more conscious of the impact of acquisitions on the stock price. Further, it is possible that acquisitions in the recent merger wave were undertaken to exploit more valuable operating synergies and that some of these greater gains were captured by acquiring-firm shareholders.

We find that from 1991 to 2001 (the 1990s), acquiring firms' shareholders lost an aggregate $\$ 216$ billion, or more than 50 times the $\$ 4$ billion they lost from 1980 to 1990 (the 1980 s), yet firms spent just 6 times as much on acquisitions in the latter period. We measure the dollar loss of acquiring-firm shareholders as the change in the acquiring firm's capitalization over the three days surrounding economically significant acquisition announcements (defined as transactions exceeding $1 \%$ of the market value of the assets of the acquirer), which we call the acquisition dollar return, and sum these losses to get the aggregate loss. Figure 1 shows the yearly aggregate losses to acquiring-firm shareholders for our sample of acquisitions of public firms, private firms, and subsidiaries from 1980 through 2001. The figure shows that the lion's share of the acquiringfirm shareholder losses took place from 1998 through 2001. After losing \$4 billion in the 1980s,

\footnotetext{
${ }^{1}$ Comment and Schwert (1995) show that $87 \%$ of exchange-listed firms are covered by poison pill rights issues, control share laws, and business combination laws in the early 1990s. They conclude "poison pills and control share laws are reliably associated with higher takeover premiums" (p. 3).
} 
acquiring-firm shareholders gained \$24 billion from 1991 through 1997 before losing \$240 billion from 1998 through 2001. The large losses from 1998 through 2001 cannot be explained by a wealth transfer from acquiring-firm shareholders to acquired-firm shareholders. We find that the aggregate combined value of acquiring and acquired firms falls by a total of $\$ 134$ billion for the sample of public firm acquisition announcements from 1998 through 2001.

To understand why acquiring-firm shareholders lost so much during the recent merger wave, we have to investigate why they lost so much at the end of the 1990s. The large aggregate dollar loss we document is not caused by a worsening of the mean abnormal return associated with acquisition announcements because, even though the mean abnormal return is lower in the late 1990s, it is still positive so that the average acquisition creates wealth for acquiring-firm shareholders. Instead, this large loss is caused by an increase in the size of the dollar losses of acquisitions with the worst dollar returns that is not offset by an equivalent increase in the size of the dollar gains of acquisitions with the best dollar returns. Statistically, the distribution of dollar returns in the late 1990 s exhibits substantially more skewness compared to earlier years. At the same time, the amount spent on the acquisitions with the worst returns increases much more than the amount spent on other acquisitions, so acquisitions with the worst returns correspond to a larger fraction of the amount spent than before. A good illustration is that the fraction of the total amount spent on acquisitions accounted for by the acquisitions in the first percentile of the distribution of dollar returns increases from $13.68 \%$ for $1980-1997$ to $32.74 \%$ for $1998-2001$.

Since the large loss of acquiring-firm shareholders is the result of a small number of acquisition announcements with extremely large losses, we investigate the bottom tail of the distribution of dollar returns to understand why the 1998-2001 acquiring-firm dollar losses differ from those in the 1980s and in the 1990s prior to 1998. Although the definition of the bottom tail of a statistical distribution is somewhat arbitrary, we choose to focus on the acquisitions with shareholder wealth losses in excess of $\$ 1$ billion, which we call the large loss deals. Out of the 4,136 acquisitions from 1998 through 2001, 87 are large loss deals. The aggregate wealth loss 
associated with these acquisitions is $\$ 397$ billion, while all other acquisitions made a total gain of $\$ 157$ billion. The large loss deals represent only $2.1 \%$ of the $1998-2001$ acquisitions, but they account for $43.4 \%$ of the money spent on acquisitions.

Why is it then that the period from 1998 through 2001 is associated with this clustering of acquisition announcements with extremely large losses for acquiring-firm shareholders? The dollar return associated with an acquisition announcement reflects both the net present value for the acquiring-firm shareholders of the acquisition itself as well as what the acquisition reveals about the acquiring firm. Firm characteristics and deal characteristics found to be important in explaining these two contributions to acquirer announcement returns explain only part of the abnormal return associated with our large loss deals. On average, large loss deals have a negative abnormal return of $-10.6 \%$. Using regression models estimated over the period 1980-1997, we can explain at most one fifth of that negative abnormal return on average.

Since Dong, Hirshleifer, Richardson, and Teoh (2003) show that firms with high valuation ratios (which they call overvalued) have poor abnormal returns, perhaps because the acquisition announcement provides evidence that management believes the firm to be overvalued, our result could be an outcome of a period with many highly valued firms. The firms that make the large loss deals have indeed high $q$ 's and low book-to-market (BM) ratios among all firms making acquisitions. The acquisition announcements of these firms are positive on average in the years immediately before they make their large loss deal even though they are also highly valued when they make these previous announcements. However, the acquisitions made by firms that make large loss deals after they announce their large loss deals are not associated with increases in shareholder wealth. The evidence is therefore consistent with the hypothesis advanced by Jensen (2003) that high valuations increase managerial discretion, making it possible for managers to make poor acquisitions when they have run out of good ones. However, the extremely poor returns of firms announcing the large loss deals and the size of the losses in comparison to the 
consideration paid suggest also that investors learn from the announcements that the stand-alone value of the announcing firms is not as high as they thought.

The paper proceeds as follows. In Section 2, we introduce our sample, document aggregate shareholder losses, and demonstrate how the distribution of acquiring-firm shareholder losses evolves through time. In Section 3, we show that the shareholder losses between 1998 and 2001 can be explained by the large loss deals and we establish in Section 4 that large loss deals are statistically and economically significant. In Section 5, firm and deal characteristics are investigated to see if they can explain the large loss deals. We investigate in Section 6 whether the large loss deals result from the extremely high valuations of the firms that announce these deals. In Section 7, we show that the firms that make large loss deals perform very poorly afterwards. We conclude in Section 8.

\section{A comparison of dollar and percentage acquisition returns in the recent merger wave to the 1980s}

To evaluate the performance of acquisitions for acquiring-firm shareholders, we focus on acquisitions that are material to the acquirer. We investigate samples of acquisitions where the deal value corresponds to $10 \%, 5 \%$, and $1 \%$ of the market value of the assets of the acquirer (defined as the book value of assets minus the book value of equity plus the market value of equity). We report results for the $1 \%$ threshold but our conclusions hold for the more restrictive samples. In addition, the sample meets the following criteria:

1. The announcement date occurs from in the period from 1980 through 2001;

2. The acquirer controls less than $50 \%$ of the shares of the target at the announcement date and obtains $100 \%$ of the target shares if the target is a public or private firm;

3. The deal value is equal to or greater than $\$ 1$ million; 
4. The target is a U.S. public firm, private firm, subsidiary, division, or branch; ${ }^{2}$

5. The acquirer is listed on CRSP and Compustat;

6. The deal is successfully completed in less than one thousand days.

Table 1 shows the number of acquisitions and the total consideration spent on acquisitions for each year in our sample. A comparison of the amount spent on acquisitions in the 1990s to the amount spent in the 1980s shows how extraordinary the volume of acquisitions of the late 1990s was: from 1998 through 2001, \$1,992 billion is spent on acquisitions, while less than a half of that amount is spent from 1991 through 1997 and roughly a quarter of that amount is spent from 1980 through 1990. Further, there are roughly twice as many acquisitions from 1998 through 2001 than through all the 1980s.

Though the literature has focused on abnormal percentage returns, these returns do not capture the change in wealth of acquiring-firm shareholders as noted by Malatesta (1983). For acquiring-firm shareholders, the same percentage return changes their wealth more if the acquirer is a large firm than if it is a small firm. Dollar returns capture the change in wealth of acquiringfirm shareholders. The sum of the dollar returns divided by the sum of the equity capitalization of the acquiring firm corresponds to a value-weighted return. We add up the dollar returns across all acquisitions each year and report the results in Table 1. Throughout the paper, we report dollar returns in 2001 dollars (obtained using the U.S. Gross Domestic Product Deflator). It is immediately clear that the years 1998 through 2001 are dramatically different from the years 1980 through 1997. From 1980 through 1997, acquiring-firm shareholders lose \$32 billion when acquisitions are announced, while acquiring-firm shareholders lost almost eight times more from 1998 through 2001. The second worst four-year period for acquiring-firm shareholders is from 1980 to 1983 , where acquiring-firm shareholders lost $\$ 5.097$ billion, or slightly more than $2 \%$ of the losses from 1998 to 2001.

\footnotetext{
${ }^{2}$ In the following, we use subsidiary acquisition to designate the acquisition of a subsidiary, a division, or a branch.
} 
Do acquiring-firm shareholders lose so much because there are more acquisitions, because the typical acquisition has a worse return, or because of some other reason? To consider the hypothesis that shareholders lose more because there are more acquisitions or firms make larger acquisitions, we can compute the average dollar loss per acquisition and the average loss per dollar spent on acquisitions. Both numbers increase dramatically from the 1980 s to the 1990 s, so that the increase in the number or dollars spent on acquisitions cannot explain mechanically why shareholders lose so much in the 1990s. From 1980 through 1990, the average dollar loss per acquisition is \$1.945 million. From 1991 through 2001, the average dollar loss is \$21.981 million, which is more than ten times more. The dollar loss per $\$ 100$ spent on acquisitions is $\$ 0.88$ cents from 1980 through 1990 and \$7.38 from 1991 through 2001.

To investigate whether shareholders lost so much because of worse abnormal returns, we estimate the abnormal returns associated with acquisitions. Table 1 reports the average abnormal return $\left(\mathrm{CAR}_{1,+1}\right)$ for each year. To estimate abnormal returns, we use standard event study methods (see Brown and Warner (1985)) and compute market model abnormal returns using the CRSP equally-weighted index returns. The parameters for the market model are estimated over the $(-205,-6)$ day interval, and the $p$-values are obtained using the time-series and crosssectional variation of abnormal returns. ${ }^{3}$ The equally-weighted abnormal return for acquiring-firm shareholders is positive every year except for two out of twenty-one. This contrasts sharply with the aggregate dollar return, which is negative for eleven years out of twenty-one. Further, the average yearly abnormal return is higher in the second half of our sample than in the first half. It is true that average yearly abnormal returns are lower from 1998 through 2001, but their average is still positive and only trivially smaller than the average across all years. ${ }^{4}$ Perhaps the most striking evidence that equally-weighted average abnormal returns are not helpful to understand

\footnotetext{
${ }^{3}$ We also calculate abnormal returns using the value-weighted CRSP market return in the estimation of the market model and in using net-of-market returns. Our results are not sensitive to using either definition of abnormal returns.
} 
the change in aggregate wealth associated with acquisition announcements is the following. From 1998 through 2001, the average abnormal return across all acquisitions is $0.69 \%$ and shareholders lose \$240 billion; from 1987 through 1990, the average abnormal return across all acquisitions is $0.76 \%$ and shareholders gain $\$ 121$ million.

If an acquisition involves synergy gains, the loss in value for the acquiring firm is more than offset by the gain of the acquired firm. Bradley, Desai, and Kim (1988) show that such an outcome is typical for their sample of takeovers. We measure the impact of the acquisition announcement on the combined value of the acquiring firm and of the acquired firm in percent returns, the abnormal return synergy gain, and in dollars, the abnormal dollar synergy gain, following the method of Bradley, Desai, and Kim (1988).

Table 1 shows the average return synergy gain and the sum of the abnormal dollar synergy gains for each year. ${ }^{5}$ The yearly sum of the abnormal dollar synergy gains exhibits the same pattern as the aggregate dollar return for acquiring-firm shareholders. In the 1980s, the aggregate dollar gain is $\$ 12$ billion. However, from 1991 through 2001, the aggregate dollar gain is a loss of $\$ 90$ billion. All of that loss and more takes place from 1998 through 2001. Simply stated, in the 1980s the target-firm shareholder dollar gains exceed the dollar losses of bidding-firm shareholders, but in the 1990s the target-firm shareholders earn less than the acquiring-firm shareholders lose.

\section{Where do the large aggregate dollar losses from 1998 through 2001 come from?}

Since dollar losses are small in the 1980s compared to 1998-2001 but the average abnormal returns do not change much, the statistical explanation for the large losses of acquiring-firm

\footnotetext{
${ }^{4}$ Harford (2003) examines industry merger waves. In his paper, abnormal returns are low at the end of such waves, but his sample has only public firm acquisitions.

${ }^{5}$ Note that the aggregate dollar synergy gain cannot be compared to the aggregate dollar bidder return because the aggregate dollar bidder return includes the dollar returns associated acquisitions of private firms and subsidiaries.
} 
shareholders must be that relatively few acquisitions were associated with extremely large dollar losses. This means that the distribution of dollar returns must have changed so the dollar returns at the lowest percentiles of the distribution of dollar returns are much worse in 1998-2001 than before. Such a change would have only a small impact on the mean abnormal return of acquisitions because it would affect the abnormal returns of a small fraction of the observations.

Figure 2 shows a box plot that illustrates how the distribution of dollar returns evolves through time. From 1998 through 2001, there are more acquisition announcements with extremely large dollar losses and gains than any other time. This corresponds to an increase in the volatility of dollar returns. Strikingly, the yearly volatility of dollar returns normalized by the consideration paid, increases dramatically also. Compared to the 1980 s, that volatility more than triples. However, more importantly, the increase in the frequency and magnitude of large dollar loss acquisitions dwarfs the increase in large dollar gain acquisitions. In statistical terms, this means that the negative skewness in the distribution of dollar returns increases sharply. This can be seen in three ways. First, we simply compute skewness for the two sub-periods. The skewness coefficient is -1.76 for $1980-1997$ and -6.99 for $1998-2001$, so skewness increases by more than three times. Second, we compute the dollar losses corresponding to the observations with dollar losses in the $5^{\text {th }}$ and $95^{\text {th }}$ percentiles of the distribution of dollar returns and normalize by the aggregate value of all transactions. The aggregate losses for the $5^{\text {th }}$ and $95^{\text {th }}$ percentiles for 1980 1997 are, respectively, $-6 \%$ and $7 \%$, so the tails of the distribution are almost symmetric. In contrast, for the second sub-period, the aggregate losses for the $5^{\text {th }}$ and $95^{\text {th }}$ percentiles are $-19 \%$ and $13 \%$ respectively, so the tails of the distribution are no longer symmetric. Third, in Figure 3 , diagnostic plots show that the distribution of dollar returns in 1998-2001 departs from a symmetric distribution more than the distribution of dollar returns in 1980-1997.

As Figure 2 shows, the large aggregate loss made by acquiring-firm shareholders is due to an increase in the frequency of acquisitions in the left tail of the distribution. To understand this 
aggregate loss, we need to understand why some acquisition announcements have such extremely large dollar shareholder wealth losses from 1998 through 2001. We therefore consider those acquisitions where the dollar loss exceeds $\$ 1$ billion in 2001 dollars and call them large loss deals. There are 87 acquisition announcements where acquiring-firm shareholders lose more than \$1 billion from 1998 to 2001. The total loss for acquiring-firm shareholders from these announcements is $\$ 397$ billion. If we exclude these 87 acquisitions, shareholders of acquiring firms gained \$157 billion from acquisition announcements from 1998 through 2001. In other words, a very small number of acquisition announcements explain why acquisition announcements are associated with an extremely large loss of acquiring-firm shareholder wealth.

These acquisitions have extremely large dollar losses for the acquiring-firm shareholders compared to the consideration paid. On average, shareholders lose $\$ 2.31$ per dollar spent on the acquisition. The median loss is $\$ 0.73$ per dollar spent. Such large losses suggest that an important component of the market's reaction to the announcement is a reassessment of the standalone value of the acquirer. In the literature, such a reassessment is often attributed to firms signaling a lack of internal growth opportunities (McCardle and Viswanatan, 1994, and Jovanovic and Braguinsky, 2002). Another source of reassessment emphasized in the literature is that firms that pay with equity signal that their equity is overpriced (Travlos, 1987).

Acquisition announcements with shareholder losses in excess of $\$ 1$ billion are unusual, as seen in Table 2 which presents the distribution of these announcements over the sample period. As is apparent, almost all large loss deals take place in the period 1998 to 2001. Symmetrically, if we define large gain deals to be those with a shareholder gain in excess of $\$ 1$ billion, such deals are unusual also. There are more large gain deals before 1998 than there are large loss deals (23 versus 17). However, from 1998 to 2001, the number of large gain deals is only $64 \%$ of the number of large loss deals. Conditional on an acquisition having a dollar return in excess of $\$ 1$ billion in absolute value, the expected loss is about $50 \%$ larger than the expected gain. If we add 
up all dollar returns from 1998 to 2001 that exceed $\$ 1$ billion in absolute value, the total is $-\$ 236$ billion, which is about equal to the total aggregate loss made by acquiring-firm shareholders.

Because the large loss deals are clustered in 1998-2001, the distribution of large loss deals differs sharply from the distribution of the whole sample of acquisitions. Though approximately $34 \%$ of the mergers $(4,136$ out of 12,023$)$ occur in $1998-2001$, about $84 \%$ of the large loss deals ( 87 out of 104) occur in the same period. In comparison, $71 \%$ of the large gain deals take place in 1998-2001. The four-year period from 1998 to 2001 represents $58 \%$ of the total amount spent on acquisitions for the entire sample, 1980 to 2001 . However, $90 \%$ of the amount spent on large loss deals is spent during that four-year period. In contrast, only $62 \%$ of the amount spent on large gain deals is spent then. From 1980 through 1997, consideration spent on large loss deals represents $6.61 \%$ of the consideration spent on acquisitions. From 1998 through 2001, 43.41\% of the amount spent on acquisitions corresponds to large loss deals. In comparison, the large gain deals are much less important since the aggregate amount spent on large gain deals is about onesixth of the aggregate amount spent on large loss deals.

\section{The statistical and economic significance of the large loss deals}

In this section, we establish that the losses associated with the 87 large loss deals from 1998 to 2001 are economically and statistically significant. These losses are significant taking into account the higher stock market volatility of the late 1990s, are not the result of large firms making acquisitions of public firms paid for with equity that have average abnormal returns, cannot be explained by industry or market returns, cannot be explained by redistribution from acquiring firms to targets, and cannot be explained by unrelated announcements.

\subsection{Are large loss deals noise resulting from more volatile stock prices?}

The last four years of our sample are years of high volatility, so it could simply be that large firms experience billion dollar changes in value frequently and the large dollar losses associated 
with acquisition announcements would not be unusual for large firms during these years. It makes no sense to test whether the cross-sectional mean of raw and abnormal returns in our sample is significantly negative. However, we can investigate whether the return of an announcing firm is significantly different from zero given the firm's time-series of returns. Using the standard deviation of returns for each firm over the period $(-205,-6)$ to evaluate whether the three-day return for each firm is significantly different from zero, we find that the three-day return is insignificant for only four firms. The average $t$-statistic for the three-day return is -5.399 and the median is -4.486 . We find similar results when we repeat the test using market model residuals.

4.2. Are large loss deals acquisitions of public firms paid for with equity by very large firms earning average abnormal returns?

Table 1 looks at all acquisitions irrespective of how they are financed and of the organizational form of the acquired firm. Moeller, Schlingemann, and Stulz (2003) show that large firms have worse acquisition abnormal returns and the average abnormal return for a large firm (defined as a firm whose capitalization in the year the acquisition is announced exceeds the $25^{\text {th }}$ percentile of NYSE firms) making a public acquisition financed with equity is $-2.45 \%$ over the period from 1980 through 2001. A firm with a market capitalization of $\$ 50$ billion whose stock price falls by $2.45 \%$ when it announces an acquisition experiences a $\$ 1.225$ billion reduction in shareholder wealth.

Can the evidence on equity-financed acquisitions of public firms having average abnormal returns explain our large loss deals? The answer is no because the abnormal return associated with our large loss deals is too large. The average abnormal return of the large loss deals over the three days surrounding the acquisition announcement is $-10.594 \%$ and the median loss is $-8.081 \%$. These negative abnormal returns are much larger than the mean and median abnormal returns for the whole sample for public firm acquisitions paid for with equity or for all 
acquisitions paid for with equity. Though the large loss deals cannot be explained by average abnormal returns of acquisitions of public firms financed with equity for the whole sample period from 1980 through 2001, the abnormal returns for acquisitions of public firms paid for with some equity worsen significantly from 1998 through 2001. From 1998 through 2001, the average abnormal return for such acquisitions by large firms is $-3.82 \%$ in contrast to $-1.47 \%$ from 1990 through 1997. The 56 large loss deals corresponding to acquisitions of public firms paid for with some equity have an abnormal return of $-11 \%$, so that without them the average abnormal return of acquisitions of public firms paid for with some equity would be $-2.94 \%$.

\subsection{Do benchmarks matter?}

The sample of large loss deals is constructed using the change in the announcing firm's capitalization (dollar return) rather than the market adjusted change (abnormal dollar return). We chose to proceed this way because we cannot exclude the possibility that some of our large loss deals may have affected the market return. The aggregate abnormal dollar return associated with the 87 large loss deals is a loss of $\$ 397$ billion in 2001 dollars, so it makes little difference whether we use the abnormal dollar return or the dollar return. If we use the dollar abnormal return to construct a sample of large loss deals, the number of large loss deals is similar.

We know that from 1998 through 2001 there were days with dramatic industry returns. The low returns of the bidders in our sample of large loss deals could therefore be due to low returns in their industry on announcement days. A priori, this explanation would do better at explaining the large loss deals in 2000 and 2001 than the earlier ones since stock prices fell on average in these years, but it is still a legitimate concern. Of the 87 large loss deals and using the SDC provided SIC codes, 38 acquirers are in manufacturing. Within the manufacturing sector, 18 of the 38 acquirers are in the electrical and electronic equipment 2-digit SIC code. To investigate industry effects, we construct a matching portfolio for each acquirer in our sample. This portfolio uses the firms in the same 4-digit SIC code as the acquirer when we can find ten firms or more 
with that SIC code. If we cannot find at least ten firms in the acquirer's 4-digit SIC code, we use the firms in the acquirer's 2-digit SIC code. Large loss deal sample firms are excluded from the matching portfolio. We then estimate the market model for the equally-weighted portfolio of the matching firms and compute the three-day abnormal return of the portfolio. Poor contemporaneous industry returns cannot explain the large loss deals. The three-day abnormal return for the matching firms is $-0.55 \%$ with a $t$-statistic of -2.085 . This abnormal return is a small fraction of the abnormal return of the acquiring firms. When we subtract the industry portfolio return from the raw return, the mean excess return is $-10.37 \%$ (the median is $-8.07 \%$ ).

\subsection{Are large loss deals wealth redistributions from bidder shareholders to target shareholders?}

By requiring acquiring firms to have a dollar announcement loss of $\$ 1$ billion, we do not constrain the percentage change or the dollar change of the combined value of the acquiring and acquired firms. Consequently, we can estimate the significance of the average percentage or dollar change in the combined value using the time-series and cross-sectional distribution for the large loss deals that correspond to acquisitions of public firms as we did in the previous section for the whole sample of public firm acquisitions. The combined value of the acquiring and acquired firm for the period 1998-2001 falls by more than 7\%, which is significantly different from zero at the one percent level. We further investigate the significance of the abnormal return using the time-series volatility of the return of the portfolio of the acquiring firm and of the acquired firm also. The average $t$-statistic is -3.312 . The percentage synergy gain is positive and significant for only five acquisitions. The dollar losses aggregate to \$212 billion. 


\subsection{Are the losses explained by news unrelated to the acquisition announcement?}

Since the aggregate dollar losses are due to few acquisitions, it could be that these acquisitions correspond to abnormal returns that can be explained by unrelated news announcements rather than by the acquisition announcement. Using Dow-Jones News Retrieval, we searched extensively for unrelated announcements during the window $(-2,+2)$ associated with the 87 large loss deals. These large loss deals are made by very large corporations, which have many news items. For some large loss deals, the bidder has positive announcements during the event window, but for others it has negative announcements. Eliminating all large loss deals with announcements that could be construed as negative, while keeping all large loss deals with positive announcements, results in an aggregate dollar loss exceeding $\$ 300$ billion dollars. Hence, the period 1998-2001 is unusual even when we use this estimate of losses biased towards zero.

\section{Can firm and deal characteristics explain the large loss deals?}

There is now a considerable literature that relates acquiring-firm abnormal returns to firm and deal characteristics. This literature finds that abnormal returns are lower for acquisitions by firms with low leverage (Maloney, McCormick, and Mitchell, 1993), low Tobin's $q$ (Lang, Stulz, and Walkling, 1989, Servaes, 1991, but not Dong, Hirshleifer, Peterson, and Teoh, 2003), large holdings of cash (Harford, 1999), low managerial share ownership (Lewellen, Loderer, and Rosenfeld, 1985), overconfident management (Malmendier and Tate, 2003), and large capitalization (Moeller, Schlingemann, and Stulz, 2003). Further, it has been shown that acquisitions of public firms (Chang, 1998, Fuller, Netter, and Stegemoller, 2002), acquisitions opposed by target management (Schwert, 2000), conglomerate acquisitions (Morck, Shleifer, and Vishny, 1990), and acquisitions with competition (Bradley, Desai, and Kim, 1998) lead to lower acquiring-firm abnormal returns. Finally, there is evidence that the relative size of the target to the bidder matters (Asquith, Bruner, and Mullins, 1983), and that equity offers are associated with 
poor bidder returns, but only for acquisitions of public firms (Travlos, 1987, Chang, 1998, Fuller, Netter, and Stegemoller, 2002). We first investigate whether the large loss deals and the firms that make them have characteristics the literature has identified as characteristics associated with poorer shareholder returns than typical acquisitions. We then evaluate whether the large loss deals and the large dollar losses associated with acquisitions from 1998-2001 can be explained with regressions models estimated using the sample from 1980 through 1997.

5.1. Do large loss deals and the firms that make them have characteristics that make low acquisition abnormal returns likely?

Panel A of Table 3 compares the large loss deals with other deals from 1998 through 2001, as well as with all deals from 1980-1997. Not surprisingly, large loss deals have a large transaction value compared to other deals, but there is nothing noticeable about the size of these deals when it is normalized by firm market value. Equity is used more often with large loss deals than with other deals and cash is used less often, which contributes to the low abnormal returns of large loss deals. Large loss deals are more likely to be hostile and more likely to be tender offers than other transactions, but the fraction of large loss deals that are tender offers or hostile is small enough that these deal characteristics cannot explain the large loss deals. The acquisitions in our large loss deal sample are more likely to be within the acquirer's industry than the other acquisitions, but the difference is not significant. The large loss deals cannot be attributed to diversification attempts.

We find next that large loss deals are overwhelmingly acquisitions of public firms compared to the sample as a whole. While 48.3\% of the acquisitions from 1998 through 2001 are acquisitions of private firms, $75.9 \%$ of the large loss deals are acquisitions of public firms, which are acquisitions with lower abnormal returns. Mitchell, Pulvino, and Stafford (2003) show that there is price pressure from the trades of arbitrageurs with acquisitions of public firms for equity. This effect would predict a rebound in the price of the acquirer following the acquisition 
announcement. Though we do not reproduce the results in a table, we examine how the cumulative abnormal returns evolve after the announcement date. The cumulative abnormal return is $-10.5 \%$ at day +10 and $-15.0 \%$ at day +60 , so there is no indication that there is a significant transitory component to the announcement abnormal return.

More competition could explain the large loss deals. We use two variables to measure competition. The first variable is the percentage of deals with actual competition. The large loss deals have a higher fraction of such deals, but this fraction is small so it cannot explain the large loss deal sample. The second measure is the liquidity index used by Schlingemann, Stulz, and Walkling (2002). This index measures the intensity of mergers and acquisitions activity within an industry. With that measure, the large loss deals seem to take place in industries with slightly less activity than the other deals.

In Panel B of Table 3, we report characteristics for the firms in our sample of large loss deals and the firms that make other acquisitions. Not surprisingly, firms that make large loss deals are big. The large loss deal firms do not have more cash than other firms, but they have lower leverage when leverage is measured using the market value of the firm's assets. We find that the Tobin's $q$ of acquiring firms in our large loss deal sample is significantly higher than the Tobin's $q$ of the other acquiring firms. A striking way to see this is to note that only 18 firms making a large loss deal have a $q$ lower than the median $q$ of all acquirers in the same year. Large loss deal firms have a significantly higher industry-adjusted $q$, which is the firm's $q$ minus the median industry $q$ when the industry is defined using the 4-digit SIC code, than other acquirers. Dong et al. (2003) use the BM ratio as one of two proxies of overvaluation. In our sample, the median BM ratio of firms when they announce a large loss deal is less than half what it is for the other firms in our sample and only 14 firms announcing large loss deals have a BM ratio higher than the median BM ratio of acquirers in the same year. Finally, there is a significant difference in operating cash flow to assets when using the mean, but there is none using the median. Large loss deal firms have somewhat lower operating cash flow. 
These comparisons between large loss deals and other acquisitions show that some of the empirical regularities of the 1980s make the large loss deals even more puzzling: the firms have higher q's, lower cash holdings, and lower operating cash flow than other firms. Competition and hostility seem to affect few large loss deals. However, most large loss deals are public firm acquisitions with a large equity component in the consideration.

5.2. Can regression models for bidder returns explain the large loss deals and the large shareholder losses from 1998 through 2001?

We investigate whether regression models of the type used in the literature to analyze bidder abnormal returns help predict the losses associated with the large loss deals. We estimate these regression models over the period from 1980 through 1997 and use the estimates to obtain fitted abnormal returns for the large loss deals from 1998 through 2001. The first four regressions in Table 4 use the whole sample. Neither the coefficient on Tobin's $q$ nor the coefficient on BM are significant. In models (1) and (2), the coefficient on the market value of leverage is positive and significant, indicating that firms with higher leverage have higher announcement returns. The liquidity index in models (3) and (4) is negative and significant, showing that acquisitions of firms that are in more liquid industries have worse abnormal returns. Finally, the coefficient on the size dummy (takes value one if a firm's equity market capitalization is below the $25^{\text {th }}$ percentile of the NYSE for the year) is positive and significant. The fitted values of the large loss deals are close to zero, so that the unexplained abnormal return using these regressions is large.

The regressions estimated so far do not include the bidder premium as an independent variable since premium data is only available for public firm acquisitions. It could be that the large loss deals are due to overpayment. To examine this, we compute a percentage premium using the stock price 50 days before the offer similar to Moeller, Schlingemann, and Stulz (2003). We estimate regressions predicting the premium offered using each of the four premium measures (not reported). The regressions offer little evidence that the premium is higher in large 
loss deals. In regressions predicting the premium, similar to those used by Officer (2003) and Schwert (2000), we find that a dummy variable for large loss deals is insignificant with three out of four premium measures. The problem may be that the premium data is too noisy. In most regressions, the coefficient on the large loss deal dummy is economically significant, typically indicating a higher premium of $8 \%$ to $10 \%$.

Regressions (5) and (6) in Table 4 are estimated only for the acquisitions for which we have premium information. In these regressions, we use the component premium since it is available at the time the abnormal returns are estimated and since the sample is substantially larger with that measure than with the initial price measure. The coefficient on the premium is insignificant in both regressions. The same result holds if we use the initial price measure. These regressions also produce fitted abnormal returns close to zero for the large loss deals.

\section{Valuation and large loss deals.}

A possible explanation for why our regressions are not useful in explaining the large loss deal abnormal returns is that these deals are explained by unique characteristics of the period from 1998 through 2001 . The late 1990s are a period with unusually high equity valuations. A number of recent papers analyze theoretically and empirically the relation between equity valuations, the propensity to undertake mergers, and the returns to bidders. In particular, Dong, Hirshleifer, Richardson and Teoh (2003) show that high valuation firms are more likely to make acquisitions and exhibit worse abnormal returns. ${ }^{7}$ Shleifer and Vishny (2003) build a model where it can be advantageous for an overvalued bidder to make acquisitions to lock in real assets and Jensen (2003) argues that overvaluation leads to high costs of managerial discretion, enabling managers to make poor acquisitions. ${ }^{8}$

\footnotetext{
${ }^{7}$ See also Rhodes-Kropf, Robinson and Vishwanathan (2003).

${ }^{8}$ Ang and Chen (2003) provide empirical evidence supportive of the model of Shleifer and Vishny (2003).
} 
The multivariate regressions in Table 4 are inconsistent with the hypothesis that there is an economically important negative relation between valuation and abnormal returns from 1980 through 1997 if a high Tobin's $q$ or a low book-to-market (BM) proxy for overvaluation. When we re-estimate these regressions from 1980 through 2001, we find that Tobin's $q$ has a significant negative coefficient of -0.0046 ( $p$-value of 0.044 ) in contrast to the earlier literature and the coefficient on BM increases also substantially (though it is still not significant). Since the large loss deal firms have such a high Tobin's $q$, the Tobin's $q$ (evaluated at the mean) between the large loss deal firms and the whole sample of acquirers corresponds to an abnormal return change of roughly $-2.5 \%$. As a result, the residual of the large loss deals is much smaller in these regressions. When we estimate regression (6) over the period from 1980 through 2001 the average residual of the large loss deals becomes $-5.35 \%$ instead of $-8.07 \%$.

It could be that the relation between abnormal returns and valuation measures is not linear and that valuation measures matter in a different way for large firms than for smaller firms. For instance, it could be that a low BM for a small firm indicates good growth opportunities but a low BM for a large firm indicates overvaluation. We construct a sub-sample for the period 1998 to 2001 of public firm acquisitions paid for with equity, where the firm is in the top decile of equity capitalization of firms making acquisitions and where the firm's BM ratio is in the bottom decile of the BM ratio of firms making acquisitions. The acquisitions in that sub-sample that are not large loss deals have a positive insignificant abnormal return of $0.86 \%$. Among firms that do not make a large loss deal we compare those with a BM lower than the average BM of large loss deal firms versus those with a higher BM and find lower BM firms do not have worse abnormal returns, whether we look at all acquisitions or only at acquisitions of public firms paid for with equity. The explanation for the large loss deals cannot therefore simply be that these firms are large firms with low BM.

To see whether the large loss deal firms make a large loss deal when their valuation is high, we compute Tobin's $q$ and the BM ratio for each year those firms announce an acquisition. We 
then compute the mean and median of the ratio of the Tobin's $q$ in the year of the large loss deal and of the Tobin's $q$ average across all acquisition years. We call this $q$ ratio minus one the normalized $q$ ratio. We would expect the normalized $q$ ratio to be zero if there is no relation between valuation and large loss deals. The mean ratio is 2.71 ( 0.46 for the median). If we use the $\mathrm{BM}$ ratio instead to construct a normalized $\mathrm{BM}$ ratio, we get -0.10 ( -0.08 for the median). Out of 76 firms, 19 firms have their highest Tobin's $q$ in the year of the large loss deal and 29 have it the year before. Similar results are obtained with the BM ratio. Strikingly, among large loss deals, the magnitude of the loss is positively correlated with the valuation of the acquirer. We estimate a logistic regression (not reported) using all acquisitions made by the firms in our large loss deal sample. The dependent variable takes value 1 for the large loss deals, while the independent variables are a constant and a dummy variable that takes a value of 1 if a firm is at its valuation peak in the year of the acquisition. The coefficient estimate on the dummy variable is significant and positive at the $1 \%$ level when we use Tobin's $q$ and negative and significant when we use BM.

The firms that make the large loss deals are serial acquirers. This makes it unlikely the large loss deal signals that a firm has run out of internal growth opportunities as in the models of McCardle and Viswanatan (1994) and Jovanovic and Braguinsky (2002)., but it is plausible it signals that the firm has run out of profitable acquisitions. If firms make poor acquisitions when they are overvalued, then acquisitions around the time a firm makes a large loss deal should have poor abnormal returns also. In Panel A of Table 5, we show the abnormal returns associated with the other acquisitions by the firms making the large loss deals for the 24 months before their (first) large loss deal from 1998 through 2001 and for the 24 months afterwards for sub-samples based on the organizational form of the assets acquired and the mode of financing of the acquisition. We find that for the two years before the large loss deal, the firms create value through acquisitions for a total of $\$ 20$ billion, which seems inconsistent with the view that high valuation firms make poor acquisitions. Before the announcement of their large loss deal, these 
firms create value in total for each type of acquisition. In the year before the large loss deal announcement, 26 firms make an economically significant acquisition and the mean abnormal return is $2 \%$. Many of these acquisitions are paid for with equity, which makes it unreasonable to believe that somehow the large loss deals have low abnormal returns simply because they involve an equity issue. However, the large loss deal is a watershed event. In the two years after the large loss deal, announcements of acquisitions are associated with a reduction in shareholder wealth of $\$ 110$ billion. The year after the large loss deal, 18 firms make an economically significant acquisition and the mean abnormal return, $-3.27 \%$, is significantly lower.

If the acquisition announcement is explained partly by negative synergies, it should be that announcements of failed offers with large dollar losses are followed by positive announcement returns when the offer is withdrawn. We searched for acquisition announcements with dollar losses in excess of $\$ 1$ billion that are subsequently withdrawn. There are very few of these. However, we investigate the abnormal return at the announcement of the withdrawal for the six cases we could find. Using the time-series volatility to estimate significance of the individual announcements, we find two announcements with significant positive abnormal returns of a magnitude similar to the announcement of the acquisition attempt, three announcements with insignificant abnormal returns to zero, and one announcement with a large significant negative abnormal return. The significant positive abnormal returns are consistent with the view that the acquisition itself destroys wealth; the insignificant abnormal returns, assuming that the withdrawal is unexpected, is consistent with the view that acquisition abnormal return is due to information revealed about the acquirer rather than the acquisition itself. We also investigate the three cases where a competitor makes an offer following a large loss deal announcement. In the three cases, the large loss deal firm experiences a positive abnormal return, which is consistent with the hypothesis that the large loss deal has negative synergy. The average of the large loss deal firm abnormal returns when the competing bid is announced is $2.24 \%$, but it is not significant. 


\section{The long-run performance of firms announcing a large loss deal.}

The extremely high Tobin's q and low BM of the firms that announce large loss deals seem to explain part of the abnormal return associated with the large loss deals, yet at the same time firms with equally lofty valuations - including the large loss deal firms before they make these deals do not have poor abnormal returns when they announce acquisitions. It seems sensible to conclude that the large loss deal firms through their announcement provide information to the market that their valuation is not justified and that earlier announcements did not provide similar information. Such an outcome could result from the acquisition destroying wealth or from the market inferring from the information conveyed by the firm that the stand-alone value of the firm is less than previously thought. Alternatively, the market could just have overreacted to the large loss deal announcements. Overreaction should lead to high subsequent returns, but overvaluation, to the extent that it is not corrected completely by the market's reaction to the announcement, should lead to poor subsequent returns.

Figure 4 presents buy-and-hold returns over the period 1998-2002 for various portfolios. The large loss deal portfolio is an equally-weighted portfolio of firms that announce a large loss deal after January 1, 1998. Whenever a firm announces a large loss deal in a given month, the portfolio is rebalanced the following month to include that firm. Consequently, the portfolio return corresponds to what an investor would have earned by investing in firms after they announced large loss deals and held that portfolio until the end of 2002. From the graph it can be seen that the portfolio has a return of approximately $-53 \%$ measured from January 1998 through the end of 2002. In contrast, an investment in the monthly CRSP value-weighted index results in a buy-and-hold return of $-5 \%$.

We also construct for each firm in our large loss deal sample an industry and size matched portfolio. Each portfolio consists of firms with the same 4-digit SIC code and the same NYSE- 
based size quartile as our sample firm. In cases where there are fewer than 10 firms available within a 4-digit SIC code, we use 2-digit SIC codes instead. The matching firms exclude firms that made a large loss deal in the 12 months preceding the portfolio formation date. The buy-andhold return of the matching-firm portfolio is $-14 \%$.

We construct a portfolio that follows the strategy of buying a large loss deal firm's matching portfolio when that large loss deal firm is added to the portfolio of large loss deals. The portfolio is an equally-weighted portfolio of each matching-firm portfolio for the firms that have announced a large loss deal since January 1, 1998 up to the month the portfolio return is computed. The excess return of the large loss deal portfolio over the matching-firm portfolio is $-39 \%$.

Finally, we estimate a regression of the monthly return of a long position in the large loss deal portfolio and a short position in the matching-firm portfolio on the Fama-French factors. ${ }^{9}$ This investment strategy has a significant intercept of $-0.85 \%$ ( $p$-value $=0.022$ ). If we add the Carhart (1997) momentum factor to the regression, the estimate of the intercept is $-0.77 \%$ ( $p$ value $=0.041$ ). These results are consistent with the view that the large loss deal firms were overvalued and this overvaluation was corrected over time, but one has to be cautious in interpreting the results since they correspond to one historical episode.

\section{Conclusion.}

We find that acquisition announcements in the 1990s are profitable in the aggregate for acquiring-firm shareholders until 1997, but the losses of acquiring-firm shareholders from 1998 through 2001 wiped out all the gains made earlier, so that acquisition announcements in the latest merger wave are costly for acquiring-firm shareholders. The losses result from relatively few acquisitions, as can be seen from the fact that from 1998 through 2001 the equally-weighted 
average abnormal return associated with acquisition announcements is positive. Without the acquisitions that lost $\$ 1$ billion or more for their shareholders in our sample, i.e., excluding just over $2 \%$ of the observations, shareholder wealth would have increased with acquisition announcements. Looking at the aggregate performance of acquisitions, the economic relevance of acquisitions with large losses overwhelms the economic relevance of the thousands of other acquisitions. It is therefore important to understand why the announcement of these acquisitions is associated with such large wealth losses. We investigate whether the results for the large loss deals are reliable and provide evidence supportive that they are. However, the aggregate dollar loss of acquiring-firm shareholders depends on relatively few deals. Though we understand well how to evaluate abnormal returns obtained by equally weighting observations, we do not understand equally well how to evaluate value-weighted abnormal returns or equivalently dollar abnormal returns.

The firms that make large loss deals are successful with acquisitions until they make their large loss deal. The high valuation of the firms announcing the large loss deals is not sufficient to explain the change in returns associated with acquisition announcements, since these firms have comparable valuations when they announce previous mergers or acquisitions that are associated with positive abnormal returns. The wealth losses associated with the acquisition announcements are likely caused by a number of reasons. In some cases, management overpays, while in others the transaction probably reveals that management's strategy is not sustainable, or more specifically that the firm has run out of profitable acquisition opportunities. However, the magnitude of the losses in comparison to the consideration paid is large enough and the performance of the firms after the announcement poor enough that in most cases the acquisitions lead investors to reconsider the extremely high stand-alone valuations of the announcing firms. To the extent that the large loss deal firms are overvalued when they make their announcement,

\footnotetext{
9 The factor loadings are obtained from Kenneth French's website (http://mba.tuck.dartmouth.edu/ pages/faculty/ken.french/data_library.html).
} 
their value would fall over time anyway, so the losses that correct the valuation of the acquiring firm do not destroy shareholder wealth for long-run shareholders. Regardless of the precise reason that explains the shareholder losses for the acquisitions in our large loss deal sample, the evidence is consistent with managements gaining an unusual amount of discretion because of the high valuations of their firms and using that discretion in a way that ends up destroying large amounts of shareholder wealth for short-term shareholders and, at least in some cases, for longterm shareholders. 


\section{References}

Andrade, G., M. Mitchell, and E. Stafford, 2001, New evidence and perspectives on mergers, Journal of Economic Perspectives 15, 103-120.

Ang, J., and Y. Chen, 2003, Direct evidence on the market-driven acquisitions theory, unpublished working paper, Florida State University, FL.

Asquith, P., Bruner, R., Mullins, D., 1983. The gains to bidding firms from merger. Journal of Financial Economics 11, 121-139.

Bates, T.W., and M. L. Lemmon, 2003, Breaking up is hard to do? An analysis of termination fee provisions and mergers outcomes, Journal of Financial Economics 69, forthcoming.

Bradley, M., A. Desai, and E.H. Kim, 1988, Synergistic gains from corporate acquisitions and their division between the stockholders of target and acquiring firms, Journal of Financial Economics 21, 3-40.

Brown, S.J., and J. B. Warner, 1985, Using daily stock returns, the case of event studies, Journal of Financial Economics 14, 3-31.

Carhart, M.M., 1997, On the persistence in mutual fund performance, Journal of Finance 52, 5782.

Chang, S., 1998, Takeovers of privately held targets, method of payment, and bidder returns, Journal of Finance 52, 773-784.

Comment, R. and G. W. Schwert, 1995, Poison or placebo? Evidence on the deterrence and wealth effects of modern antitakeover measures, Journal of Financial Economics 39, 3-43.

Dong, M., D. Hirshleifer, S. Richardson, and S. H. Teoh, 2003, Does investor misvaluation drive the takeover market?, unpublished working paper, The Ohio State University, Columbus, OH.

Fama, E.F., and K. French, 1992, The cross-section of expected stock returns, Journal of Finance 47, 427-465.

Fama, E.F., and K. French, 1993, Common risk-factors in the returns on stocks and bonds, Journal of Financial Economics 33, 3-56.

Fuller, K., J. Netter, and M. Stegemoller, 2002, What do returns to acquiring firms tell us? Evidence from firms that make many acquisitions, Journal of Finance 57, 1763-1794.

Harford, J., 1999. Corporate cash reserves and acquisitions. Journal of Finance 54(6), 1969-1997

Harford , J., 2003, Merger waves: Hubris, herding, or efficient response to a shock?, University of Washington working paper.

Jensen M. C., 2003, Agency costs of overvalued equity, work in progress.

Jovanovic, B., Braguinsky, S., 2002. Bidder discounts and target premia in takeovers. NBER working paper \#9009, NBER, Cambridge, MA. 
Lang, L. H. P., Stulz, R. M., Walkling, R. A., 1989. Managerial performance, Tobin's Q, and the gains from successful tender offers. Journal of Financial Economics 24, 137-154.

Lewellen, W., C. Loderer, and A. Rosenfeld, 1985, Merger decisions and executive stock ownership in acquiring firms, Journal of Accounting and Economics, 7, 209-231.

McCardle, K.F., Viswanathan, S., 1994. The direct entry versus takeover decision and stock price performance around takeovers. Journal of Business 67, 1-43.

Malatesta, P., 1983, The wealth effect of merger activity and the objective function of merging firms, Journal of Financial Economics 11, 155-182.

Malmendier, U., and G.A. Tate, 2003, Who makes acquisitions? CEO overconfidence and the market's reaction, Harvard Business School Working Paper.

Maloney, M.T., R.E. McCormick, and M.L. Mitchell, 1993, Managerial decision making and capital structure, Journal of Business 66, 189-217.

Mitchell, M., T. Pulvino, and E. Stafford, 2003, Price pressure around mergers, Journal of Finance, forthcoming.

Moeller, S.B., F.P. Schlingemann, and R.M. Stulz, 2003, Firm size and the gains from acquisitions, Journal of Financial Economics, forthcoming.

Morck, R., Shleifer, A., Vishny, R.W., 1990. Do managerial objectives drive bad acquisitions? Journal of Finance 45, 31-48.

Officer, M., 2003. Termination fees in mergers and acquisitions. Journal of Financial Economics 69 , forthcoming.

Rhodes-Kropf, M., D.T. Robinson, and S. Viswanathan, 2003, Valuation waves and merger activity: The empirical evidence, working paper, Columbia University, New York, NY.

Rhodes-Kropf, M., and S. Viswanathan, 2003, Market valuation and merger waves, working paper, Columbia University, New York, NY.

Schlingemann, F.P., R.M. Stulz, and R.A. Walkling, 2002, Divestitures and the liquidity of the market for corporate assets, Journal of Financial Economics 64, 117-144.

Schwert, G. W., 2000, Hostility in takeovers: In the eyes of the beholder?, Journal of Finance 55, 2599-2640.

Servaes, H., 1991. Tobin's q, agency costs, and corporate control: An empirical analysis of firm specific parameters. Journal of Finance 46, 409-419.

Shleifer A., and R.W. Vishny, 2003, Stock market driven acquisitions, Journal of Financial Economics, forthcoming.

Travlos, N.G., 1987, Corporate takeover bids, methods of payment, and bidding firms' stock returns, Journal of Finance 42, 943-963. 


\section{Figure 1}

\section{Yearly aggregate dollar return of acquiring-firm shareholders (1980-2001)}

Data is from the SDC Mergers and Acquisitions Database. The graph shows the aggregate dollar return associated with acquisition announcements for each sample year. The aggregate dollar return is defined as the sum of the product of the abnormal return of each announcement multiplied by the equity capitalization of the acquirer.

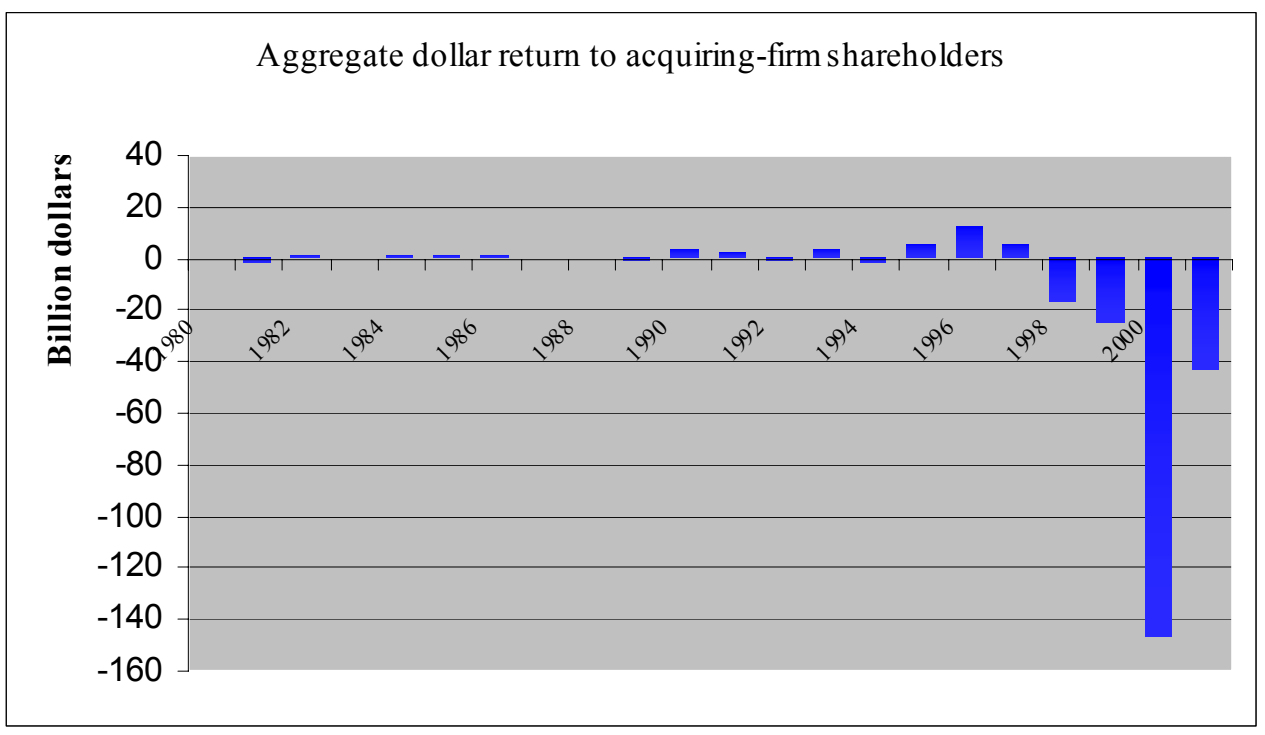




\section{Figure 2}

Box plot of the dollar return of acquiring-firm shareholders (1980-2001)

Data is from the SDC Mergers and Acquisitions Database. The graph shows the box plot of the inflation adjusted dollar returns (in 2001 million dollars) associated with acquisition announcements by year. These returns are calculated by subtracting the market value of publicly traded equity at the close of event day +1 minus the market value on the close of event day -2 . The solid line represents a billion dollar return loss so the large loss deals are to the left of the line.

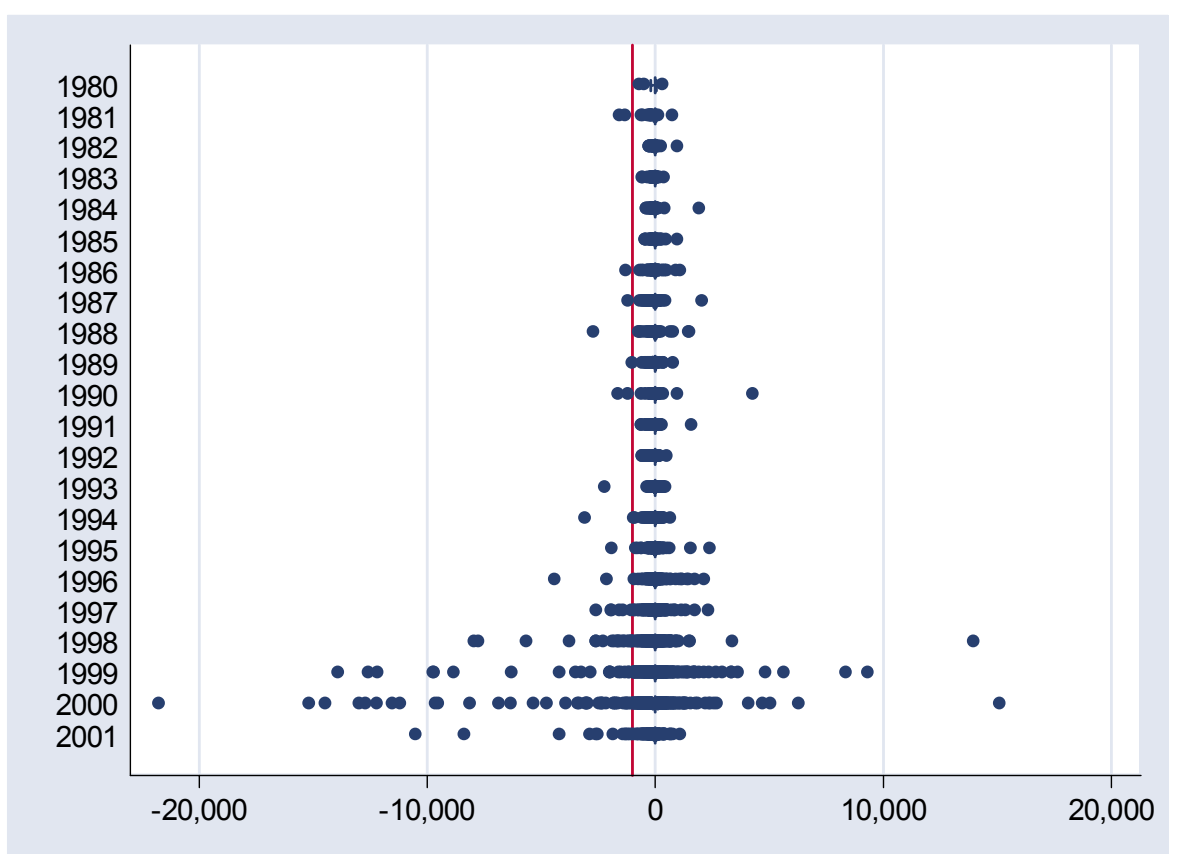




\section{Figure 3. Symmetry plots.}

Dollar return symmetry plots showing each value of dollar return for a period plotted against the reference line $(y=x)$. Under perfect symmetry, each point would lie along the reference line. The more points above (below) the reference line, the more the distribution is skewed to the right (left).

\section{Panel A. Years 1980-1997}

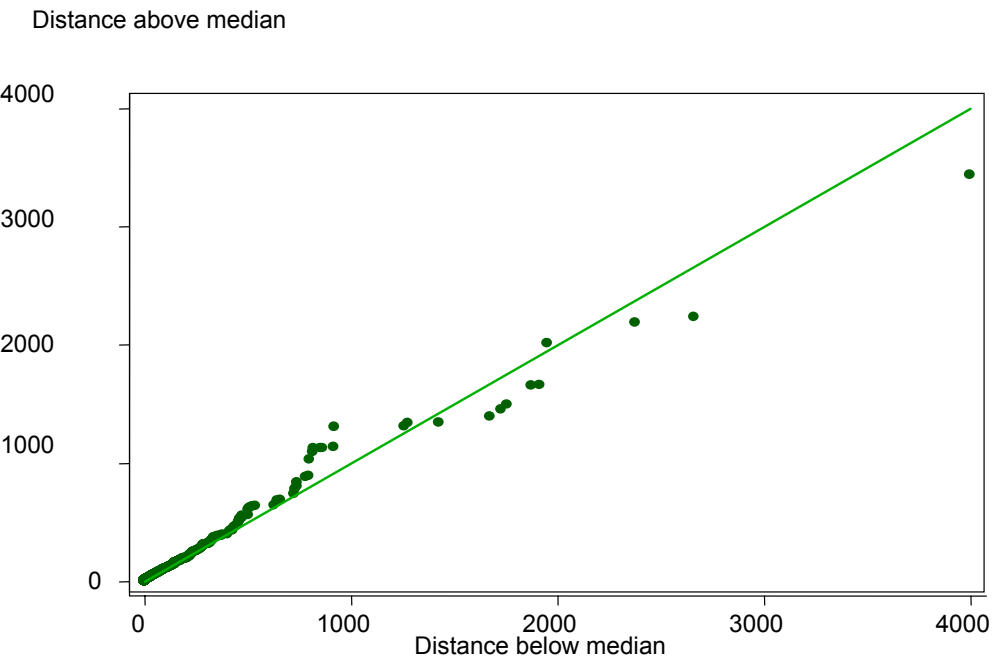

Panel B. Years 1998-2001.

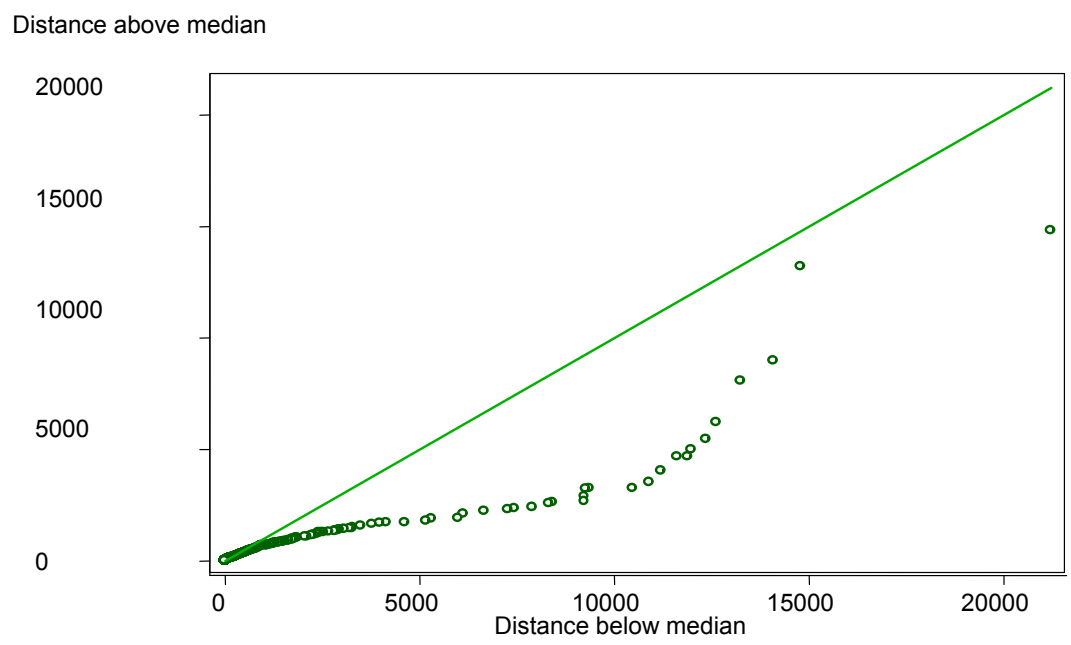




\section{Figure 4}

\section{Monthly buy-and-hold returns (1998-2002)}

The figure plots monthly buy-and-hold returns (decimal returns) over the period 1998-2002 for various portfolios. The large loss deal portfolio is an equally-weighted portfolio of firms that announced a large loss deal since January 1, 1998. Whenever a firm announces a large loss deal in a given month, the portfolio is rebalanced the following month to include that firm. The industry portfolios are constructed for each firm in our large loss deal sample and consist of firms with the same 4-digit SIC code and the same NYSE-based size quartile as our sample firm. In case there are fewer than 10 firms available within a 4digit SIC code, we use 2-digit SIC codes. The matching firms exclude firms that are in the large loss sample with the announcement date within 12 months prior to the portfolio date. The difference portfolio follows the strategy of buying a long position in the large loss deal portfolio and a short position in the matching-firm portfolios. The value-weighted index is from CRSP.

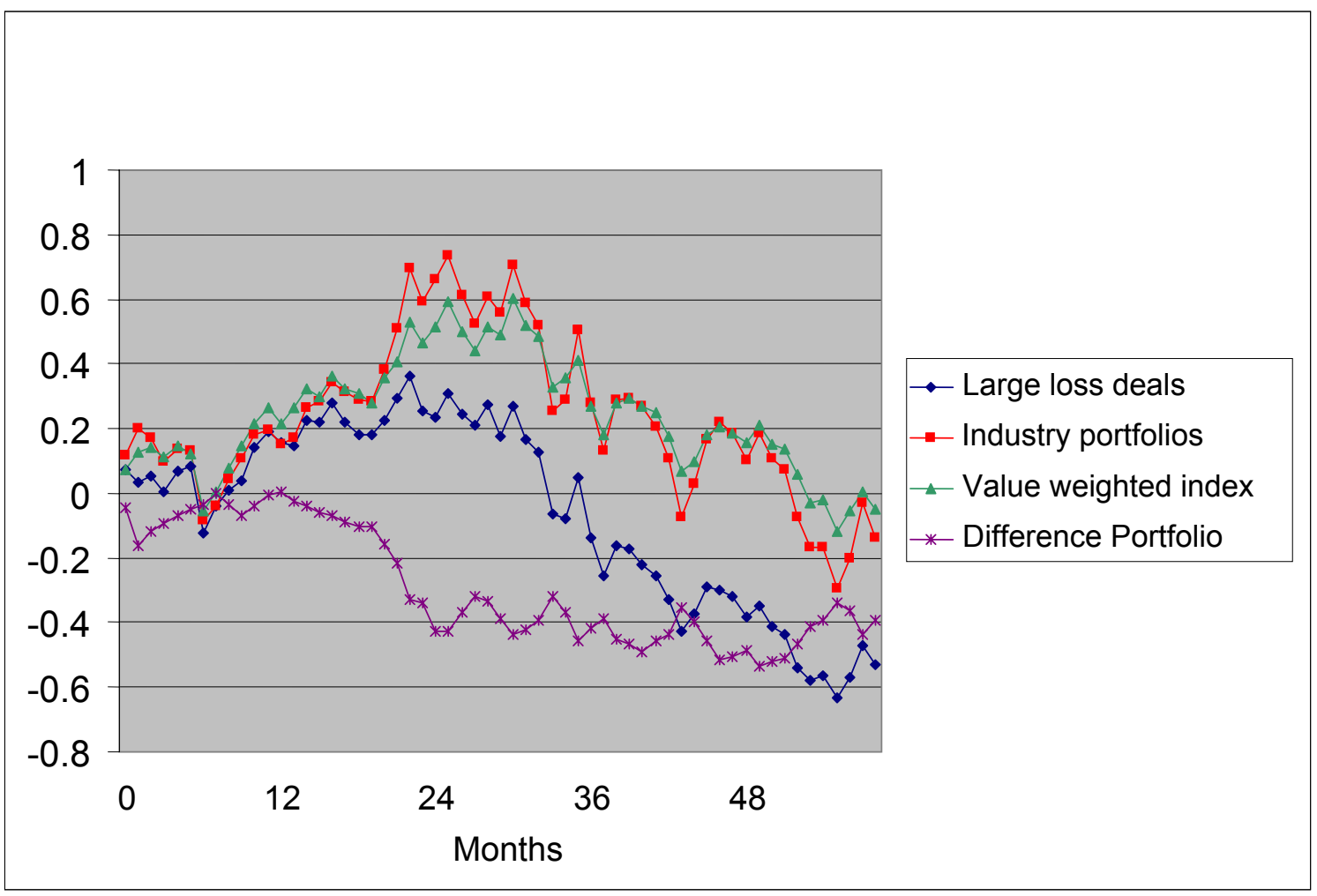




\section{Table 1}

\section{Full Sample Distribution of Aggregate Transaction Values, Dollar Returns. and Percentage Returns Sorted by Announcement Year}

The Bidder columns represent the sample of successful acquisitions by publicly listed U.S. acquirers from the SDC Merger and Acquisition Database of U.S. targets that are private firms, public firms, or subsidiaries. The Synergy columns only represent acquisitions where target stock price data is available. Bidder $n$ lists the number of observations. Aggregate Transaction Value (in 2001 million dollars) is the total value of consideration paid by the acquirer, excluding fees and expenses. Aggregate Dollar Return (in 2001 million dollars) is calculated by subtracting the market value of publicly traded equity at the close of event day +1 minus the market value on the close of event day -2 then adding up the dollar returns within the year. $\mathrm{CAR}_{(-1,+1)}$ denotes the 3-day cumulative abnormal return (in percent) measured using the market model. For synergy, the Abnormal Return Gain (in 2001 million dollars) is the average cumulative abnormal return over the $(-1,+1)$ event window for the value-weighted portfolio of the target and bidder return. The weights for the bidder and the target are based on the market value of equity two days prior to the announcement. The target weight adjusts for the percentage of target shares held by the acquirer prior to the announcement of the deal. Abnormal returns are defined as market model residuals, where the parameters are estimated over the $(-205,-6)$ event window relative to the announcement day. The abnormal dollar synergy gain is defined as the abnormal return synergy gain times the sum of the market value of equity for the bidder and the target in million dollars, adjusted for the percentage of target shares held by the acquirer prior to the announcement of the deal. The Aggregate Dollar Gain is the sum of the synergy gains over all acquisitions for which target stock returns are available. $n$ lists the number of synergy observations.

\begin{tabular}{|c|c|c|c|c|c|c|c|}
\hline \multirow[b]{4}{*}{ Year } & \multicolumn{4}{|c|}{ Bidder } & \multicolumn{3}{|c|}{ Synergy } \\
\hline & & Aggregate & Aggregate & & Abnormal & Aggregate & \\
\hline & & Transaction & Dollar & & Return & Dollar & \\
\hline & $n$ & Value & Return & $\mathrm{CAR}_{(-1,+1)}$ & Gain & Gain & $n$ \\
\hline 1980 & 22 & 5,461 & $-1,292$ & 0.0063 & 0.0099 & -662 & 12 \\
\hline 1981 & 113 & 33,172 & $-4,781$ & -0.0089 & 0.0025 & -153 & 35 \\
\hline 1982 & 149 & 29,851 & 1,128 & 0.0086 & 0.0407 & 1,014 & 39 \\
\hline 1983 & 214 & 31,587 & -152 & 0.0036 & 0.0007 & -939 & 32 \\
\hline 1984 & 281 & 46,925 & 324 & 0.0100 & 0.0354 & 4,310 & 48 \\
\hline 1985 & 157 & 69,116 & 221 & -0.0043 & 0.0256 & 3,947 & 57 \\
\hline 1986 & 245 & 62,029 & 188 & 0.0124 & 0.0251 & 1,864 & 45 \\
\hline 1987 & 216 & 52,364 & $-1,028$ & 0.0108 & 0.0286 & 2,977 & 55 \\
\hline 1988 & 225 & 66,762 & -399 & 0.0039 & 0.0276 & -492 & 53 \\
\hline 1989 & 304 & 52,808 & $-1,258$ & 0.0063 & 0.0212 & 926 & 39 \\
\hline 1990 & 256 & 32,530 & 2,806 & 0.0095 & 0.0252 & $-1,194$ & 33 \\
\hline 1991 & 304 & 32,875 & 1,539 & 0.0279 & 0.0235 & 2,329 & 35 \\
\hline 1992 & 475 & 41,278 & $-1,295$ & 0.0186 & 0.0102 & -996 & 37 \\
\hline 1993 & 633 & 71,178 & 2,627 & 0.0182 & 0.0167 & 364 & 65 \\
\hline 1994 & 804 & 110,213 & $-3,189$ & 0.0153 & 0.0097 & 4,233 & 110 \\
\hline 1995 & 896 & 164,857 & 5,439 & 0.0126 & 0.0140 & 10,236 & 151 \\
\hline 1996 & 1,076 & 214,611 & 13,305 & 0.0157 & 0.0270 & 18,322 & 162 \\
\hline 1997 & 1,517 & 303,720 & 5,211 & 0.0136 & 0.0166 & 9,021 & 230 \\
\hline 1998 & 1,508 & 560,497 & $-18,829$ & 0.0094 & 0.0058 & -284 & 223 \\
\hline 1999 & 1,115 & 632,016 & $-26,616$ & 0.0086 & 0.0112 & $-25,893$ & 214 \\
\hline 2000 & 885 & 549,011 & $-151,127$ & 0.0036 & -0.0054 & $-78,652$ & 161 \\
\hline 2001 & 628 & 250,321 & $-43,382$ & 0.0026 & -0.0055 & $-28,843$ & 131 \\
\hline $1980-1990$ & 2,182 & 482,604 & $-4,244$ & 0.0064 & 0.0241 & 11,599 & 448 \\
\hline $1991-2001$ & 9,841 & $2,930,576$ & $-216,316$ & 0.0120 & 0.0104 & $-90,163$ & 1,519 \\
\hline $1998-2001$ & 4,136 & $1,991,845$ & $-239,954$ & 0.0069 & 0.0029 & $-133,672$ & 729 \\
\hline $1980-2001$ & 12,023 & $3,413,180$ & $-220,560$ & 0.0110 & 0.0135 & $-78,564$ & 1,967 \\
\hline
\end{tabular}


Table 2

\section{Large loss deals sample distribution sorted by announcement year}

Large loss deals are acquisitions with a dollar return in 2001 dollars corresponding to a loss of at least $\$ 1$ billon selected from the sample of successful acquisitions by publicly listed U.S. acquirers from the SDC Merger and Acquisition Database of U.S. targets that are private firms, public firm, or subsidiaries. $n$ lists the number of observations. Aggregate Transaction Value (in 2001 million dollars) is the total value of consideration paid by the acquirer, excluding fees and expenses. Aggregate Dollar Return (in 2001 million dollars) is calculated by subtracting the market value of publicly traded equity at the close of event day +1 minus the market value on the close of event day -2 then adding up the dollar returns within the year. $\mathrm{CAR}_{(-1,+1)}$ denotes the 3 -day cumulative abnormal return (in percent) measured using the market model.

\begin{tabular}{lrrr}
\hline Announcement & $n$ & Aggregate & $\begin{array}{r}\text { Aggregate } \\
\text { Year }\end{array}$ \\
\hline 1980 & 0 & Transaction Value & $\$ 0$ \\
1981 & 2 & 17,000 & $-2,782$ \\
1982 & 0 & 0 & 0 \\
1983 & 0 & 0 & 0 \\
1984 & 0 & 0 & 0 \\
1985 & 0 & 0 & 0 \\
1986 & 1 & 617 & $-1,237$ \\
1987 & 1 & 219 & $-1,152$ \\
1988 & 1 & 6,957 & $-2,659$ \\
1989 & 0 & 0 & 0 \\
1990 & 2 & 9,316 & $-2,748$ \\
1991 & 0 & 0 & 0 \\
1992 & 0 & 0 & 0 \\
1993 & 7,243 & $-2,180$ \\
1994 & 1 & 4,559 & $-3,034$ \\
1995 & 1 & 3,640 & $-1,866$ \\
1996 & 1 & 18,258 & $-6,468$ \\
1997 & 2 & 26,202 & $-9,184$ \\
1998 & 216,792 & $-46,912$ \\
1999 & 5 & 290,565 & $-98,765$ \\
2000 & 17 & 254,361 & $-211,250$ \\
2001 & 19 & 102,986 & $-39,661$ \\
\hline All & 38 & $\$ 958,715$ & $-\$ 429,897$ \\
\hline
\end{tabular}


Table 3

Firm and deal characteristics: Large loss deals versus other deals

In column (1) large loss deals for the period 1998-2001 represent deals where the dollar return loss is at least \$1 billion, column (2) presents the other deals for the period 1998-2001 and column (3) all deals for the period 1980-1997, including large loss deals for that period. The transaction value ( $\$$ million) is the total value of consideration paid by the acquirer, excluding fees and expenses. The number of days to completion is measured as the number of days between the announcement and effective dates. The liquidity index for the target is calculated as the value of corporate control transactions for each year and two-digit SIC code divided by the total book value of assets of firms in the two-digit SIC code for that year (e.g., Schlingemann, Stulz, and Walkling (2002)). Cash and equity in the consideration paid is from SDC. Same industry deals involve targets with a 2-digit SIC code identical to the one of the bidder. Cash includes cash and marketable securities and is normalized by the book value of assets. Tobin's $q$ is defined as the book value of assets minus the book value of equity plus the market value of equity, divided by the book value of assets. Book-to-market is defined as in Fama and French (1992). Industry-adjusted $q$ and book-to-market are defined as the raw value minus the yearly 2-digit SIC code based median value. Operating cash flow (OCF) is defined as sales minus the cost of goods sold, sales and general administration and working capital change. Medians are in brackets and $p$-values of differences are based on $t$-tests (means) and Wilcoxon-tests (medians). Respectively, ${ }^{\mathrm{a}},{ }^{\mathrm{b}}$, and ${ }^{\mathrm{c}}$ denote statistical significance between large loss and other deals at the $1 \%, 5 \%$, and $10 \%$ level.

\begin{tabular}{|c|c|c|c|c|c|c|}
\hline & $\begin{array}{l}\text { 1998-2001 } \\
\text { Large loss }\end{array}$ & $\begin{array}{c}1998-2001 \\
\text { Other }\end{array}$ & $\begin{array}{c}1980-1997 \\
\text { All }\end{array}$ & \multicolumn{3}{|c|}{ Differences } \\
\hline & $(1)$ & $(2)$ & (3) & $(1)-(2)$ & $(2)-(3)$ & $(1)-(3)$ \\
\hline Transaction value (TV) & $\begin{array}{c}9,586 \\
{[2,837]}\end{array}$ & $\begin{array}{l}268 \\
{[40]}\end{array}$ & $\begin{array}{l}149 \\
{[26]}\end{array}$ & $\begin{array}{c}9,317^{\mathrm{a}} \\
{[2,797]^{\mathrm{a}}}\end{array}$ & $\begin{array}{l}119^{\mathrm{a}} \\
{[14]^{\mathrm{a}}}\end{array}$ & $\begin{array}{c}9,437^{\mathrm{a}} \\
{[2,811]^{\mathrm{a}}}\end{array}$ \\
\hline TV/ Assets (market) & $\begin{array}{c}0.198 \\
{[0.075]}\end{array}$ & $\begin{array}{c}0.157 \\
{[0.060]}\end{array}$ & $\begin{array}{c}0.200 \\
{[0.062]}\end{array}$ & $\begin{array}{c}0.042 \\
{[0.014]}\end{array}$ & $\begin{array}{c}-0.043^{\mathrm{c}} \\
{[-0.001]}\end{array}$ & $\begin{array}{c}-0.002 \\
{[0.013]}\end{array}$ \\
\hline TV/ Equity (market) & $\begin{array}{c}0.267 \\
{[0.102]}\end{array}$ & $\begin{array}{c}0.296 \\
{[0.108]}\end{array}$ & $\begin{array}{c}0.355 \\
{[0.124]}\end{array}$ & $\begin{array}{c}-0.029 \\
{[-0.007]}\end{array}$ & $\begin{array}{c}-0.059^{\mathrm{a}} \\
{[-0.016]^{\mathrm{a}}}\end{array}$ & $\begin{array}{l}-0.088^{\mathrm{b}} \\
{[-0.022]}\end{array}$ \\
\hline Days to completion & $\begin{array}{l}125.8 \\
{[94.0]}\end{array}$ & $\begin{array}{c}67.0 \\
{[41.0]}\end{array}$ & $\begin{array}{c}88.4 \\
{[59.0]}\end{array}$ & $\begin{array}{c}58.8^{\mathrm{a}} \\
{[53.0]^{\mathrm{a}}}\end{array}$ & $\begin{array}{c}-21.4^{\mathrm{a}} \\
{[-18.0]^{\mathrm{a}}}\end{array}$ & $\begin{array}{c}37.4^{\mathrm{a}} \\
{[35.0]^{\mathrm{a}}}\end{array}$ \\
\hline Cash in payment $(\%)$ & 22.6 & 56.9 & 52.8 & $-34.3^{\mathrm{a}}$ & $4.1^{\mathrm{a}}$ & $-30.3^{\mathrm{a}}$ \\
\hline Equity in payment (\%) & 71.6 & 35.2 & 30.3 & $36.4^{\mathrm{a}}$ & $4.9^{\mathrm{a}}$ & $41.3^{\mathrm{a}}$ \\
\hline Pure cash deal (\%) & 10.3 & 41.1 & 40.4 & $-30.7^{\mathrm{a}}$ & 0.6 & $-30.1^{\mathrm{a}}$ \\
\hline Pure equity deal (\%) & 51.7 & 25.8 & 23.7 & $25.9^{\mathrm{a}}$ & $2.1 \mathrm{~b}$ & $28.0^{\mathrm{a}}$ \\
\hline Tender-offer (\%) & 12.6 & 3.0 & 4.3 & $9.7^{\mathrm{a}}$ & $-1.4^{\mathrm{a}}$ & $8.3^{\mathrm{b}}$ \\
\hline Hostile deal (\%) & 1.1 & 0.1 & 0.6 & $1.0^{\mathrm{b}}$ & $-0.5^{\mathrm{a}}$ & 0.5 \\
\hline Same industry (\%) & 41.4 & 31.6 & 33.2 & $9.8^{\mathrm{c}}$ & $-1.6^{\mathrm{c}}$ & 8.2 \\
\hline Private target (\%) & 14.9 & 51.7 & 44.1 & $-36.7^{\mathrm{a}}$ & $7.6^{\mathrm{a}}$ & $-29.2^{\mathrm{a}}$ \\
\hline Public target (\%) & 75.9 & 20.9 & 21.9 & $54.9^{\mathrm{a}}$ & -1.0 & $54.0^{\mathrm{a}}$ \\
\hline Subsidiary target (\%) & 9.2 & 27.4 & 34.0 & -18.2 & $-6.6^{\mathrm{a}}$ & $-24.8^{\mathrm{a}}$ \\
\hline Competed deal (\%) & 8.0 & 0.7 & 1.4 & $7.4^{\mathrm{b}}$ & $-0.7^{\mathrm{a}}$ & $6.6^{\mathrm{b}}$ \\
\hline Liquidity index & $\begin{array}{c}0.117 \\
{[0.102]}\end{array}$ & $\begin{array}{c}0.151 \\
{[0.080]}\end{array}$ & $\begin{array}{c}0.084 \\
{[0.036]}\end{array}$ & $\begin{array}{c}-0.034^{\mathrm{b}} \\
{[0.022]}\end{array}$ & $\begin{array}{c}0.067^{\mathrm{a}} \\
{[0.044]^{\mathrm{a}}}\end{array}$ & $\begin{array}{c}0.033^{\mathrm{b}} \\
{[0.066]^{\mathrm{a}}}\end{array}$ \\
\hline
\end{tabular}


Table 3 - continued

\begin{tabular}{|c|c|c|c|c|c|c|}
\hline \multicolumn{7}{|c|}{ Panel B: Acquirer Characteristics } \\
\hline & $\begin{array}{l}\text { 1998-2001 } \\
\text { Large loss }\end{array}$ & $\begin{array}{c}\text { 1998-2001 } \\
\text { Other }\end{array}$ & $\begin{array}{c}1980-1997 \\
\text { All }\end{array}$ & \multicolumn{3}{|c|}{ Differences } \\
\hline & $(1)$ & $(2)$ & (3) & $(1)-(2)$ & $(2)-(3)$ & $(1)-(3)$ \\
\hline Assets (book) & $\begin{array}{c}39,308 \\
{[14,631]}\end{array}$ & $\begin{array}{l}2,546 \\
{[360]}\end{array}$ & $\begin{array}{l}2,227 \\
{[268]}\end{array}$ & $\begin{array}{c}36,762^{\mathrm{a}} \\
{[14,271]^{\mathrm{a}}}\end{array}$ & $\begin{array}{c}318 \\
{[92]^{\mathrm{a}}}\end{array}$ & $\begin{array}{c}37,080^{\mathrm{a}} \\
{[14,363]^{\mathrm{a}}}\end{array}$ \\
\hline Market Capitalization & $\begin{array}{c}49,307 \\
{[28,368]}\end{array}$ & $\begin{array}{l}2,145 \\
{[383]}\end{array}$ & $\begin{array}{c}959 \\
{[213]}\end{array}$ & $\begin{array}{c}47,162^{\mathrm{a}} \\
{[27,985]^{\mathrm{a}}}\end{array}$ & $\begin{array}{l}1,186^{\mathrm{a}} \\
{[170]^{\mathrm{a}}}\end{array}$ & $\begin{array}{c}48,347^{\mathrm{a}} \\
{[28,155]^{\mathrm{a}}}\end{array}$ \\
\hline Cash / Assets (book) & $\begin{array}{c}0.176 \\
{[0.058]}\end{array}$ & $\begin{array}{c}0.170 \\
{[0.059]}\end{array}$ & $\begin{array}{c}0.142 \\
{[0.073]}\end{array}$ & $\begin{array}{c}0.006 \\
{[-0.001]}\end{array}$ & $\begin{array}{c}0.028^{\mathrm{a}} \\
{[-0.014]}\end{array}$ & $\begin{array}{c}0.034^{\mathrm{c}} \\
{[-0.016]}\end{array}$ \\
\hline Debt / Assets (book) & $\begin{array}{c}0.441 \\
{[0.468]}\end{array}$ & $\begin{array}{c}0.473 \\
{[0.462]}\end{array}$ & $\begin{array}{c}0.467 \\
{[0.452]}\end{array}$ & $\begin{array}{c}-0.031 \\
{[0.006]}\end{array}$ & $\begin{array}{c}0.006 \\
{[0.010]}\end{array}$ & $\begin{array}{l}-0.025 \\
{[0.016]}\end{array}$ \\
\hline Debt / Assets (market) & $\begin{array}{c}0.176 \\
{[0.169]}\end{array}$ & $\begin{array}{c}0.302 \\
{[0.265]}\end{array}$ & $\begin{array}{c}0.315 \\
{[0.285]}\end{array}$ & $\begin{array}{c}-0.127^{\mathrm{a}} \\
{[-0.096]^{\mathrm{a}}}\end{array}$ & $\begin{array}{l}-0.012^{\mathrm{b}} \\
{[-0.021]^{\mathrm{a}}}\end{array}$ & $\begin{array}{c}-0.139^{\mathrm{a}} \\
{[-0.117]^{\mathrm{a}}}\end{array}$ \\
\hline Tobin's $q$ & $\begin{array}{c}6.643 \\
{[3.208]}\end{array}$ & $\begin{array}{c}2.698 \\
{[1.538]}\end{array}$ & $\begin{array}{c}1.919 \\
{[1.396]}\end{array}$ & $\begin{array}{c}3.945^{\mathrm{a}} \\
{[1.670]^{\mathrm{a}}}\end{array}$ & $\begin{array}{c}0.778^{\mathrm{a}} \\
{[0.142]^{\mathrm{a}}}\end{array}$ & $\begin{array}{c}4.723^{\mathrm{a}} \\
{[1.812]^{\mathrm{a}}}\end{array}$ \\
\hline Ind. Adjusted Tobin's $q$ & $\begin{array}{c}5.032 \\
{[1.604]}\end{array}$ & $\begin{array}{c}1.186 \\
{[0.177]}\end{array}$ & $\begin{array}{c}0.469 \\
{[0.035]}\end{array}$ & $\begin{array}{c}3.845^{\mathrm{a}} \\
{[1.427]^{\mathrm{a}}}\end{array}$ & $\begin{array}{c}0.717^{\mathrm{a}} \\
{[0.142]^{\mathrm{a}}}\end{array}$ & $\begin{array}{c}4.562^{\mathrm{a}} \\
{[1.570]^{\mathrm{a}}}\end{array}$ \\
\hline $\mathrm{BM}_{\text {(equity) }}$ & $\begin{array}{c}0.231 \\
{[0.178]}\end{array}$ & $\begin{array}{c}0.482 \\
{[0.409]}\end{array}$ & $\begin{array}{c}0.591 \\
{[0.520]}\end{array}$ & $\begin{array}{c}-0.251^{\mathrm{a}} \\
{[-0.231]^{\mathrm{a}}}\end{array}$ & $\begin{array}{c}-0.108^{\mathrm{a}} \\
{[-0.111]^{\mathrm{a}}}\end{array}$ & $\begin{array}{c}-0.360^{\mathrm{a}} \\
{[-0.343]^{\mathrm{a}}}\end{array}$ \\
\hline Ind. Adjusted BM (equity) & $\begin{array}{c}-0.246 \\
{[-0.270]}\end{array}$ & $\begin{array}{c}-0.043 \\
{[-0.114]}\end{array}$ & $\begin{array}{c}0.032 \\
{[-0.030]}\end{array}$ & $\begin{array}{c}-0.203^{\mathrm{a}} \\
{[-0.156]^{\mathrm{a}}}\end{array}$ & $\begin{array}{c}-0.076^{\mathrm{a}} \\
{[-0.084]^{\mathrm{a}}}\end{array}$ & $\begin{array}{c}-0.279^{\mathrm{a}} \\
{[-0.240]^{\mathrm{a}}}\end{array}$ \\
\hline OCF / Assets (book) & $\begin{array}{c}0.061 \\
{[0.079]}\end{array}$ & $\begin{array}{c}0.072 \\
{[0.076]}\end{array}$ & $\begin{array}{c}0.286 \\
{[0.136]}\end{array}$ & $\begin{array}{l}-0.012 \\
{[0.003]}\end{array}$ & $\begin{array}{c}-0.213^{\mathrm{a}} \\
{[-0.060]^{\mathrm{a}}}\end{array}$ & $\begin{array}{c}-0.225^{\mathrm{b}} \\
{[-0.057]^{\mathrm{a}}}\end{array}$ \\
\hline
\end{tabular}




\section{Table 4}

\section{Predicted change in acquiring-firm shareholder wealth from multiple regressions of bidder}

three-day announcement returns estimated over the 1980-1997 period

Large loss deals are transactions that have a dollar return corresponding to a loss of over $\$ 1$ billion dollars. Premium is defined as the aggregate consideration divided by the market value of target equity 50 days prior to the announcement. Premium values less than zero or larger than 2 are eliminated. Premium data is available only for public targets. Large Loss $\varepsilon_{1998-2001}$ and Large Loss $\hat{y}_{1998-2001}$ denote the average residual and average predicted value of each model for the large loss deals in the 1998-2001 period. For each variable we list the coefficient and the heteroscedasticity-consistent $p$-value (in italics). The last rows report the adjusted- $\mathrm{R}^{2}$ and the number of observations. Year and one-digit main industry classification dummies are included but not reported in all models. Respectively, ${ }^{\mathrm{a}},{ }^{\mathrm{b}}$, and ${ }^{\mathrm{c}}$ denote statistical significance at the $1 \%, 5 \%$, and $10 \%$ level.

\begin{tabular}{|c|c|c|c|c|c|c|}
\hline & $(1)$ & $(2)$ & (3) & $(4)$ & $(5)$ & (6) \\
\hline Constant & $\begin{array}{c}-0.0077 \\
0.670\end{array}$ & $\begin{array}{c}-0.0064 \\
0.729\end{array}$ & $\begin{array}{c}0.0056 \\
0.733\end{array}$ & $\begin{array}{c}0.0048 \\
0.772\end{array}$ & $\begin{array}{c}0.0154 \\
0.531\end{array}$ & $\begin{array}{c}0.0129 \\
0.597\end{array}$ \\
\hline Debt / Assets (market) & $\begin{array}{c}0.018^{\mathrm{b}} \\
0.021\end{array}$ & $\begin{array}{c}0.0168^{\mathrm{b}} \\
0.036\end{array}$ & $\begin{array}{c}0.0085 \\
0.238\end{array}$ & $\begin{array}{c}0.0057 \\
0.434\end{array}$ & $\begin{array}{c}0.0025 \\
0.872\end{array}$ & $\begin{array}{c}-0.0139 \\
0.423\end{array}$ \\
\hline Book to market (equity) & $\begin{array}{c}0.0004 \\
0.934\end{array}$ & & $\begin{array}{c}-0.0033 \\
0.466\end{array}$ & & $\begin{array}{c}-0.0125 \\
0.131\end{array}$ & \\
\hline Tobin's $q$ & & $\begin{array}{c}-0.0004 \\
0.616\end{array}$ & & $\begin{array}{c}-0.0003 \\
0.757\end{array}$ & & $\begin{array}{c}-0.002 \\
0.361\end{array}$ \\
\hline Private target & & & $\begin{array}{c}-0.0065^{\mathrm{a}} \\
0.010\end{array}$ & $\begin{array}{c}-0.0065^{\mathrm{a}} \\
0.010\end{array}$ & & \\
\hline Public target & & & $\begin{array}{c}-0.0224^{\mathrm{a}} \\
0.001\end{array}$ & $\begin{array}{c}-0.0224^{\mathrm{a}} \\
0.001\end{array}$ & & \\
\hline Same industry & & & $\begin{array}{c}0.0033 \\
0.151\end{array}$ & $\begin{array}{c}0.0034 \\
0.137\end{array}$ & $\begin{array}{l}0.014^{\mathrm{b}} \\
0.024\end{array}$ & $\begin{array}{c}0.0133^{\mathrm{b}} \\
0.033\end{array}$ \\
\hline Tender-offer & & & $\begin{array}{c}0.0053 \\
0.306\end{array}$ & $\begin{array}{l}0.005 \\
0.335\end{array}$ & $\begin{array}{c}-0.0052 \\
0.451\end{array}$ & $\begin{array}{c}-0.0063 \\
0.353\end{array}$ \\
\hline Hostile deal & & & $\begin{array}{c}-0.0039 \\
0.690\end{array}$ & $\begin{array}{c}-0.0036 \\
0.712\end{array}$ & $\begin{array}{c}-0.002 \\
0.866\end{array}$ & $\begin{array}{c}-0.0007 \\
0.952\end{array}$ \\
\hline Competed deal & & & $\begin{array}{c}-0.0061 \\
0.362\end{array}$ & $\begin{array}{c}-0.0059 \\
0.374\end{array}$ & $\begin{array}{c}-0.0183^{c} \\
0.062\end{array}$ & $\begin{array}{c}-0.0182^{c} \\
0.061\end{array}$ \\
\hline Equity in payment & & & $\begin{array}{c}-0.0026 \\
0.419\end{array}$ & $\begin{array}{c}-0.0021 \\
0.505\end{array}$ & $\begin{array}{c}-0.0339^{\mathrm{a}} \\
0.001\end{array}$ & $\begin{array}{c}-0.033^{\mathrm{a}} \\
0.001\end{array}$ \\
\hline TV / Equity (market) & & & $\begin{array}{c}0.0106^{\mathrm{a}} \\
0.001\end{array}$ & $\begin{array}{c}0.0106^{\mathrm{a}} \\
0.001\end{array}$ & $\begin{array}{c}0.0062 \\
0.155\end{array}$ & $\begin{array}{c}0.0063 \\
0.146\end{array}$ \\
\hline Liquidity Index & & & $\begin{array}{c}-0.008^{\mathrm{c}} \\
0.068\end{array}$ & $\begin{array}{c}-0.0081^{\mathrm{c}} \\
0.064\end{array}$ & $\begin{array}{c}0.0045 \\
0.604\end{array}$ & $\begin{array}{l}0.005 \\
0.565\end{array}$ \\
\hline OCF / Assets (book) & $\begin{array}{c}-0.0006 \\
0.622 \\
\end{array}$ & $\begin{array}{c}-0.0006 \\
0.633 \\
\end{array}$ & $\begin{array}{c}-0.0005 \\
0.683 \\
\end{array}$ & $\begin{array}{c}-0.0005 \\
0.718 \\
\end{array}$ & $\begin{array}{c}-0.0058 \\
0.545\end{array}$ & $\begin{array}{c}-0.0045 \\
0.648 \\
\end{array}$ \\
\hline
\end{tabular}


Table 4 - Continued

\begin{tabular}{lcccccc}
\hline & $(1)$ & $(2)$ & $(3)$ & $(4)$ & $(5)$ & $(6)$ \\
\hline Small & $0.0227^{\mathrm{a}}$ & $0.0226^{\mathrm{a}}$ & $0.0176^{\mathrm{a}}$ & $0.0172^{\mathrm{a}}$ & $0.0199^{\mathrm{b}}$ & $0.0179^{\mathrm{b}}$ \\
& 0.001 & 0.001 & 0.001 & 0.001 & 0.013 & 0.024 \\
Premium & & & & & -0.0067 & -0.0060 \\
& & & & & 0.251 & 0.307 \\
Large Loss $\varepsilon_{1998-2001}$ & -0.1017 & -0.1007 & -0.0942 & -0.0925 & -0.0892 & -0.0807 \\
Large Loss $\hat{y}_{1998-2001}$ & -0.0059 & -0.0069 & -0.0134 & -0.0150 & -0.0130 & -0.0215 \\
$n$ & 6,596 & 6,596 & 6,584 & 6,584 & 770 & 770 \\
Adjusted-R & 0.024 & 0.025 & 0.056 & 0.056 & 0.050 & 0.049 \\
\hline
\end{tabular}




\section{Table 5}

\section{Merger activity of firms with at least one large loss deal}

The windows are formed on the first large loss deal a firm has in 1998-2001 where year 0 includes the year before (after) the announcement for the pre- (post-) announcement windows. In Panel A, information on acquisitions in two-year windows immediately before and immediately after the first large loss deal a firm makes are provided by consideration and target organizational form. Panel B shows yearly windows around the first large loss deal a firm has in the 1998 to 2001 period. The abnormal returns over the $(-1,+1)$ eventwindow, $\mathrm{CAR}_{(-1,+1)}$, are market model residuals. The inflation adjusted abnormal dollar return, $\$$ Return $_{(\$ 2001)}$, is calculated by subtracting the market value of publicly traded equity at the close of event day +1 minus the market value on the close of event day -2 .

\begin{tabular}{|c|c|c|c|c|c|c|}
\hline Years & Consideration & $\begin{array}{c}\text { Target } \\
\text { Organizational } \\
\text { Form } \\
\end{array}$ & $\begin{array}{c}\text { Number } \\
\text { of } \\
\text { Firms } \\
\end{array}$ & $\begin{array}{c}\text { Mean \# } \\
\text { Transactions } \\
\text { per Firm } \\
\end{array}$ & $\begin{array}{l}\text { CAR }_{(-1,+1)} \\
\text { Abnormal } \\
\text { Return (\%) } \\
\end{array}$ & $\begin{array}{c}\text { Aggregate } \\
\text { Abnormal } \\
\text { \$Return }_{(\$ 2001)} \\
\end{array}$ \\
\hline \multicolumn{7}{|c|}{ Panel A: Acquisitions in the two years before and after the large loss deal sorted by consideration } \\
\hline$[-2,0]$ & No Equity & Private & 4 & 1.0 & 12.22 & $\$ 2,586.2$ \\
\hline$[-2,0]$ & No Equity & Public & 5 & 1.0 & 0.02 & 460.9 \\
\hline$[-2,0]$ & No Equity & Subs & 7 & 1.0 & 0.91 & $1,587.1$ \\
\hline$[-2,0]$ & Some Equity & Private & 4 & 1.0 & 8.66 & $2,095.7$ \\
\hline$[-2,0]$ & Some Equity & Public & 8 & 1.1 & -1.74 & 365.9 \\
\hline$[-2,0]$ & Some Equity & Subs & 1 & 1.0 & 5.08 & $1,383.8$ \\
\hline$[-2,0]$ & All Equity & Private & 13 & 1.7 & 3.44 & $7,817.5$ \\
\hline$[-2,0]$ & All Equity & Public & 17 & 1.3 & -0.65 & $2,696.3$ \\
\hline$[-2,0]$ & All Equity & Subs & 3 & 1.0 & 4.27 & $1,531.2$ \\
\hline$[0,+2]$ & No Equity & Private & 1 & 1.0 & -4.11 & $-1,149.9$ \\
\hline$[0,+2]$ & No Equity & Public & 3 & 1.0 & -1.53 & $-9,188.7$ \\
\hline$[0,+2]$ & No Equity & Subs & 6 & 1.2 & 3.63 & $1,9011.6$ \\
\hline$[0,+2]$ & Some Equity & Private & 2 & 1.0 & -2.54 & $-3,337.8$ \\
\hline$[0,+2]$ & Some Equity & Public & 4 & 1.5 & -4.14 & $-12,321.4$ \\
\hline$[0,+2]$ & Some Equity & Subs & 1 & 1.0 & -6.14 & -547.6 \\
\hline$[0,+2]$ & All Equity & Private & 3 & 1.0 & -3.24 & $-16,668.1$ \\
\hline$[0,+2]$ & All Equity & Public & 8 & 1.4 & -5.74 & $-86,401.7$ \\
\hline \multicolumn{7}{|c|}{ Panel B: Acquisitions before and after the large loss deal } \\
\hline$[-6,-3]$ & & & 27 & 2.1 & 0.70 & $\$ 5,049.3$ \\
\hline$[-3,-2]$ & & & 20 & 1.4 & -2.39 & $1,075.3$ \\
\hline$[-2,-1]$ & & & 26 & 1.4 & 1.99 & $8,054.5$ \\
\hline$[-1,0]$ & & & 26 & 1.5 & 2.03 & $12,470.0$ \\
\hline$[0,+1]$ & & & 18 & 1.2 & -3.27 & $-45,041.0$ \\
\hline$[+1,+2]$ & & & 10 & 1.2 & -2.66 & $-65,562.5$ \\
\hline$[+2,+3]$ & & & 5 & 1.2 & -0.45 & $-4,907.6$ \\
\hline$[+3,+6]$ & & & 2 & 1.0 & -0.10 & -273.5 \\
\hline
\end{tabular}

